\title{
The Influence of Confucianism in the Law Code of the Nguyen Dynasty of Vietnam
}

\author{
Vu Hong Van ${ }^{1^{*}}$, Nguyen Xuan Phong ${ }^{2}$, Pham Duy Hoang ${ }^{3}$ \\ ${ }^{1}$ University of Transport and Communications, Vietnam \\ ${ }^{2}$ Academy of Journalism and Communication, Vietnam \\ ${ }^{3}$ The People's Security College II, Vietnam
}

\begin{abstract}
DOI: $10.36348 /$ jaep.2020.v04i05.003 $\quad$ | Received: 05.05.2020 | Accepted: 14.05.2020 | Published: 17.05 .2020
\end{abstract}
*Corresponding author: Vu Hong Van

\section{Abstract}

Confucianism was born twenty-five centuries and has lasted for so long over a wide area including China, Korea, Japan and Vietnam. That is one thing that needs to explain why. Explaining this would certainly be difficult to convince if the mere theory of its richness and depth. It must have the conditions to be born and exist in the socio-economic base of East Asia, first of all in China, where it was born. The conditions for its birth only exist in China, but the conditions for its long-term survival are in all three countries of Korea, Japan and Vietnam and must be similar to those in China, at least about culture generally. In the history of Vietnam, since independence, the feudal dynasties of Vietnam have begun to use Confucianism was an effective way to govern and manage society. It is not surprising that the laws enacted by the feudal dynasties of Vietnam all have Confucianism imprints. Those were ancient laws code; the most typical was built and issued in Vietnamese history (from the 11th century to the 19th century). Based on the study of ancient bibliographies, in consultation with researchers and colleagues, this study provides insights and assessments of the Confucian imprints in the Hoang Viet Luat Le (called the Gia Long law) of Nguyen Dynasties of Vietnam; It also raises some controversial issues about the position and role of Confucianism in the history of Nguyen Dynasty Vietnam so that colleagues and researchers continue to study and debate.

Keywords: Confucianis, ancient laws, feudal dynasties, Vietnam.

Copyright @ 2020: This is an open-access article distributed under the terms of the Creative Commons Attribution license which permits unrestricted use, distribution, and reproduction in any medium for non-commercial use (NonCommercial, or CC-BY-NC) provided the original author and sources are credited.

\section{INTRODUCTION}

In 938, Ngo Quyen defeated the Nam Han army on the Bach Dang River, opening a new era - the era of independence of the Vietnamese nation. However, instability still occurs [1]. It was not until Ly Cong Uan ascended the throne, establishing the Ly Dynasty that the country of Vietnam truly came into stability and development. After the establishment of the Dynasty, along with the establishment of national sovereignty, development of the socio-cultural economy of the country, the Ly kings, firstly Ly Thai To who focused on revival and develop ancient Vietnamese culture to a new level, with new nuances [2]. As the first Dynasty of the period of independence and autonomy, the Ly Dynasty acted as the first Dynasty to open, establish and create the basic money for the development of the following dynasties at all and aspects of culture such as religious activities, beliefs, literature - arts, folk festivals, etc. In particular, it was noticeable as the first marks in the reception of the Confucianism ideology of the Ly Dynasty. Starting from there, the monarchy and feudal states in Vietnam were aware of the role of law and cared about and invested in the enactment of the law. The Vietnamese legal system in this period consisted of general laws and other legal documents such as Chieu, Chi, Le, Lenh, $\mathrm{Du}$, Sac, etc. In which, the laws: Hinh Thu (Ly Dynasty), Quoc Trieu Hinh Luat (called Hinh Luat Tran Dynasty), Quoc Trieu Hinh Luat (called the Hong Duc law - Later Le Dynasty) [3]; especially is the Hoang Viet Luat Le (called the Gia Long law - Nguyen Dynasty). Those were ancient codes the most typical was built and issued in Vietnamese history (from the 11 th century to the early 20th century). The main and throughout ideology in the Laws is expressed in two main contents: first, the concept of the people and the role of the people; secondly, the virtue of king, the virtue of people, king - functionary, king - people and king - functionary relationship. These ideologies, to a certain extent, had influenced of Confucianist conception of country governance and determined the social relationships that everyone must follow. However, those laws have been developed and 
regulated by the conditions of Vietnamese society, by the requirements and practical tasks set for the feudal class, for the Vietnamese people, etc [4]. Because so that thought went beyond the classic books of the Confucian sages; contribute to meeting the requirements and tasks of defending and building the country, in line with the development trend of Vietnamese society in the independent feudal period. It has undeniable positive values.

For the Nguyen Dynasty, Confucianism became the dominant ideology, regarded by the Nguyen Dynasty as "the state religion". Therefore, in the way of ruling the country, especially in the legal system, the influence of Confucianism is very deep [5].

\section{The Nguyen dynasty}

The Nguyen Dynasty (1802-1945) began with the reign of King Gia Long, who was the dynasty's founder and ended with the reign of King Bao Dai who was the last monarch time of Vietnam. Prior to the Nguyen Dynasty, were the nine Nguyen Lords, who deserves credit for extending the territory southwards [6].

In 1558, the first Lord Nguyen Hoang, came to be the garrison chief of Thuan Hoa (Hue province today) and opened a new page in this territory's history [6]. The more developed and consolidated the regime of the Nguyen became, the fiercer was the struggle with the Trinh from the North. This situation resulted in a civil war lasting more than 200 years. Simultaneously, the process of widening their territory southwards was also strongly promoted. By 1757, the Nguyen Lords had established their sovereignty over the entire south region [3].

In the process of establishing and developing the government over the southern region (Dang Trong), the Nguyen Lords had moved and set the capital from Ai Tu (1558-1570) to Tra Bat (1570-1600), Dinh Cat (1600-1626), Phuoc Yen (1626-1636), Kim Long (1636-1687), Phu Xuan (1687-1712), Bac Vong (17121738) then returned to Phu Xuan again (1738-1775) [3]. In 1775 , as the result of many socio-political factors, the last Nguyen Lord lost Phu Xuan into the hands of the northern Trinh Lord. This was followed by the complete collapse of the Trinh regime to the power of Tay Son forces. The Nguyen did not recover until one of their descendants retrieved their fortune and established the Nguyen Dynasty.

In 1802, after he defeated the forces of Tay Son, Nguyen Anh, who was a descendant of Nguyen Lords, unified the country and established the Nguyen dynasty. During his reign, he took the name is Gia Long [7].

Phu Xuan became the capital of the country for the next 143 years (1802-1945). King Gia Long of the Nguyen Dynasty built up Phu Xuan as the powerful political and cultural center of a unified Vietnam [8]. It reflected the enhancement of the country's territory and concentrated the cultural values of a vast territory. The Nguyen Dynasty also left a huge heritage including a number of national historical books, national gazetteers, and the repertory of the administrative regulations, epitaphs, royal edicts, land registers, family records and suchlike.

Most importantly, the tangible cultural heritage of not only this dynasty but also of the earlier dynasties was all well restored and preserved during the Nguyen dynasty. Due to this policy, many heritage buildings from the Ly Dynasty to the later the Le Dynasty, such as Mot Cot Pagoda, Tran Quoc pagoda, and Dau pagoda, remain until the present day [9].

\section{Influence of Confucianism in the law code of Nguyen dynasty \\ The Overview of Hoang Viet Luat Le}

As mentioned above, for the Nguyen Dynasty, Confucianism became the dominant ideology, regarded by the Nguyen Dynasty as "the state religion". Therefore, in the way of ruling the country, especially in the legal system, the influence of Confucianism is very deep [10].

After the weakening of the Le Dynasty, Vietnam fell into civil war for three centuries, until Nguyen Anh founded the Nguyen Dynasty in 1802. To consolidate the feudal regime, protect the royal power and stabilize it. After a long period of social upheaval, immediately after taking the throne, King Gia Long immediately sent a group of officials draft a new law. In 1815, Hoang Viet Luat Le was issued.

The Hoang Viet Luat Le was also known as: Hoang Trieu Luat Le, Quoc Trieu Luat Le, Nguyen Trieu Hinh Luat, Gia Long law. King Gia Long, after ascending the throne to have a legal basis, ordered Nguyen Van Thanh, Vu Trinh and Tran Huu to rely on Qing Dynasty law and Hong Duc Law as the basis for preparing the Nguyen Dynasty's law called Hoang Viet Luat Le, also known as Gia Long law, had 22 volumes and 398 articles [7].

The Hoang Viet Luat Le had 398 articles and 30 articles cited, written in 22 volumes, there were six categories corresponding to six ministries: Lai, Cong, Le, Ho, Binh and Hinh. Details are as follows [11]:

Volume 1: table of contents, table (or chart), rules of funeral attire, terminology interpretation.

Volume 2 and 3: 45 articles of Danh Le.

Volume 4 and 5: 27 articles of Lai Luat.

Volume 6, 7 and 8: 66 articles of Ho Luat.

Volume 9: 26 articles of Le Luat.

Volume 10 and 11: 58 articles of Binh Luat.

Volume 12 to 20: 166 articles of Hinh Luat. 
Volume 21: 10 articles of Cong Luat.

Volume 22: Guidance for law implementation.

The Hoang Viet Luat Le was built on the basis of reviewing and referring to the Hong Duc law, but mostly borrowed from the Qing Dynasty, although it was amended and updated to suit the specific conditions of Vietnam at that time [12]. Of the 398 articles, 397 was a transcript of Qing Dynasty law. Only one thing was drawn from the Hong Duc law [11].

The Hoang Viet Luat Le was an important tool to build and consolidate the centralized monarchy state. It can be seen that the law always mentions the issue of protecting national sovereignty, the protection of sovereignty comes from the request to protect the Confucianism monarchy. As we all know, the core of Confucianism political ideology is the policy of rituals, upholding the virtue of thepolitician, especially following all standards to be in accordance with the ceremony. So the laws of Dynasty all took the content of ideas from Confucianism. Gia Long law also took that Confucianism law ideology as the theoretical basis used to direct the application method and legislative principles of the law. It could be said that Gia Long law was the most concentrated expression of Confucianism thought in Vietnamese feudal law.

\section{The Imprint of Confucianism}

In his policy of ruling the country, King Gia Long especially emphasized the role of "Thien Tu", this is the throughout thought in the policy of rule of feudal dynasties of China, Korea, Japan and Vietnam. King Gia Long applied the Confucianism ideology in making laws, also emphasize that thought. In the preface of the Hoang Viet Luat Le, King Gia Long wrote: "I think: The people saints who rule the people all use the law to punish, use morality to educate them" [13]. Indeed, living in society, people with endless desires, if there is no law to prevent them, there is no way to lead people to the path of moral education.

The Hoang Viet Luat Le instituted the righteous views of Confucianism in order to force the mandarins to perform according to their functions as aide and exercise the power of the king according to their position. List of rules: vol. 2, article 6 about the offender officials, wrote: "If the officials commit crimes, they cannot be tried individually, but must present and ask for the king's opinion. If the King agrees to be allowed to be questioned and subject to the impeachment law, then he will inform the King and wait for the King's decision [7]. The law also stipulates that mandarins have had loyal absolute obligations to the king. Article 12 of the Criminal Code, article 1 about conspiracy to oppose clearly, states: "If a servant dares to conspire against the king, destroy the temple, or jeopardize the Dynasty, it was treason, conspirators or accomplices were executed" [11].
In addition, in the ceremonial laws as in volume 4, section 10, article 10, wrote:" If does not come to court to attend work, not to the workplace", will punished, it was an act of disrespect to the king, and his superior, so he will was punished [7]. Acts of infringement upon royal rituals and abuse of privileges belonging to the king were also strictly punished. Volume 9, section Lễ Luật, the rite section, article 1 of Hiep Hoa states that: "If the royal physician concocts medicine for the king without prescription, the outside record is wrong, he will be fined 100 whips. The medicine offered to the king, be respectfully prepared according to the original prescription, not to be confused ", "Cook food for the king but violate taboo food, the cook will be fined 100 whips ", "Utensils and vehicles of the king go, caregivers store remodeling without proper permission will be fined 60 whips" [7].

The Three Moral Bonds (Tam Cuong), the Five Constant Virtues (Ngu Thuong) of Confucianism were also clearly shown in feudal laws, and Hoang Viet Luat Le was no exception. These were the basic moral principles of feudal society and the maintenance of King's power was its nucleus. In article 2, volume 1 part Danh Le about the evil crimes, including crimes: treason, betrayal, rebellion, immorality, great disrespect, filial piety, disloyalty and rebellion. These are 10 crimes that cannot be forgiven for violating the Confucian basic theory, about the discipline of the king, father and son, husband and wife, threatening the stability of feudal society and consolidation of monarchy.

The ultimate goal of the laws was to increase power, protect the king and the court. Therefore, even filial piety must take a step back in case of a conflict between loyal to the king and filial piety with parents. It can be said that feudal laws were the will of the king, the basic tool to protect the interests of the king and the interests of the royal court.

Confucianism advocated a combination of ceremony and penaltly, complementing each other in order to effectively maintain the maintenance of longterm security and national stability and social stability. Ceremony is about preventing crime, leading people towards good. Confucius once said: "Ceremony is the category of culture; the latter is determined by the nature of man" 14]. Therefore, the Ceremony is firstly understood as rituals and ethical norms defining the relationship between people and humans in the order of the social status of the Zhou Dynasty. Ceremony is considered to be a right, an obligation that everyone is obliged to obey. Filial piety with parents, brotherhood harmony, faithfulness of friends ... higher than another level which was the discipline of the country, the social order that regulates human behavior. Thanks to the Ceremony, each person has a sustainable basis to abstain from his mistress and perform his humanity in his life ... Thanks to the Feast, "he, she can cultivate his 
Vu Hong Van et al; J Adv Educ Philos, May., 2020; 4(5): 201-207

or her own character into the traditional ethical habits and habits" [15]. In Hoang Viet Luat Le, demanding the division of property when living out of the house is one of the filial piety: "All living parents and grandparents, their children and grandchildren are not allowed to have their own property. If you want to divide the property into private, it is a filial act" [36], or when grandparents and parents are still alive, their children and grandchildren are not able to show respect for their property, even though their parents no longer have their brothers and sisters together, they must be more polite to the elders. Making laws like that is how to teach people to be filial. Those provisions of Gia Long law have shown the idea of respect for the elderly, mercy on the elderly, brothers and sisters of love ... it clearly shows the initiation of filial piety in Confucianism.

The nature of the ritual and the punishment reflected the interests and wills of the ruling class. Rituals and punishments are complementary to each other, taking the ceremony as the leader, taking the punish as a model, taking the ceremony to change people's ideas and opinions, making the people understand Ceremony; using punish to warn the evil world, making people aware of the majesty of the law; use rituals to love and care for the people, promote law enforcement, and at the same time use punish to code morals, causing people to build up a righteous morality.

The close association between Ceremony and punish in the laws has protected the traditional values of the nation such as filial piety, respect for grandparents, parents of descendants, harmony between husband and wife, respect compromise between brothers, the tradition of religious respect ... At the same time, it had a great effect in adjusting behavior in the family, making people aware of their obligations, responsibilities and self-fulfillment. Duties in each specific position with his family. Thus the law is the foundation for ethical education in the family and in society, upholding traditional ethical standards and values.

In East Asian countries in general and in Vietnam in particular, the traditional moral and ethical issues are always geared towards building a sustainable, long-term family. The Analects saying: "The man who has just been born has to be a filial and harmonious son, who has devoted his whole life to his family and took the job of building a family to be happy for himself. Happiness and personal honor are closely linked with happiness and family honor" [36]. Gia Long law also advocated using the law to direct family relations according to such Confucianism morality, in order to create a Confucianism family power. In the evil crimes, there are 4 crimes belonging to the scope against family morality: filial piety, rebellion, disrespect, and disagreement. Through the tool, family morality has brought into the minds of the people the awareness of "filial piety, gratitude, and respect", concepts which were both morality and legal thought attached to the body of political mechanisms in which they live to guide behaviors and lifestyles.

Gia Long's law allowed the family members to protect and conceal each other's crimes, prohibiting denunciation of parents and grandparents - that is a tradition of filial piety of Vietnamese people has been institutionalized into the law for many generations. On the surface, this regime of concealment is against the law, but the profound nature reflects deeply the Confucianism moral ethics. In the hearts of every Vietnamese person, ever since he was born, he has been educated and behaved according to this principle, which is the duty that he must respect and be respectful to his parents and his parents, and respect the glass above. The Vietnamese believe that filial piety is the personality of the person, the root of religion as a human being, and a noble social value. In the volum 1 of the Danh Luat Le, article 31 of the relative acquaintance (relatives and relatives concealing each other's crimes) stated: "In case of relatives of the everybody who are in grave mourning, his grandparents, his grandmother, his parents-in-law, his son-in-law, his husband, his brothers and his wife are very grateful, if they commit crimes, they can hide their crimes from each other" [7]. Or in volume 2 of the Danh Le, article 17 stated: "If you commit a crime of imprisonment, exile, and an elderly parent who has no caregiver, he will beaten 100 whips, the other crime gives you a ransom, at home to take care of parent" [7]. This showed clearly the advantage of filial piety, even if there is conflict between filial piety and the law, filial piety is considered the root to regulate human behavior. Confucianism promotes filial piety and related ceremonies, making the close blood relation with the family fully affirmed. Piety was the feeling of being protected naturally by people towards close relatives. Piety was an important key to maintaining close family relationships. It protected the apostolic regime, minimized the disruption of the Confucianis family order, thus preserving the moral values in the family, which were also the moral values of Confucianism.

The humanitarian ideology in Gia Long law was most clearly expressed in humane regulations such as: leniency policy for offenders, protection of the elderly and children; helping disabled and disadvantaged people, people in difficult circumstances and those who are guilty have confessed.

One of the main views of Vietnamese people is respect the elderly and love children. So in Gia Long law also applied in some laws for these two subjects. As shown in volume 3 of Danh Le, article 21 stated: "If the elderly are 70 years old or older, children 15 years old and under and people disabled (damaged eyes, broken legs) guilty of being saved downwards for redemption ... The elderly 80 years old or older, children 10 years old or younger seriously ill, committing murder, 
Vu Hong Van et al; J Adv Educ Philos, May., 2020; 4(5): 201-207

conspiracy will be summoned to the king awaiting the decision of king, etc. Elderly 90 years or older, children 7 years old or younger even if they commit a crime of death, there is no penalty ..." [7]. Article 22 then writes: "While committing crimes but not yet old, not yet disabled, but when the offenses are discovered, they shall be dealt with according to the crimes of old age and disability". volum 19 of Hinh Luat, article 10 stipulates: "Those who are over 70 years old (compassion for the elderly), 15 years old or younger (because of their love for the young), disabled (love disabled people) if they commit a crime, the official is not allowed to use the interrogation penalty, only based on the evidence that condemns the crime" [7].

Despite being influenced by Confucianism ideology about gender prejudice, there are some provisions in Gia Long law that pays some attention to the rights and status of women. In feudal times, the status of women was greatly underestimated, but to some extent, the dignity of the woman was still appreciated and respected. The law prohibits and punishes people who commit fraud to get married. Volume 7 of the Law on Marriage, Article 12, Forced to win of a woman, wrote: "Forcing a wife and a daughter to be sold to others as a concubine, or to a royal family, or to a royal court of honor, awaiting stranglehold" [7]. Or in Volume 7 of the Law on Marriage, Article 15 of Leaving wife, states: "If a husband leaves his wife and goes away for 3 years, during that period he does not inform, then leaves, he will punish 80 whips, arbitrarily get more wives will punish 100 whips" [10]. Thus the man was more responsible for women, more concerned about his family.

Vietnamese people always uphold and protect the good moral values of people, such as their kindness, filial piety towards parents, spousal gratitude ... Those ethical standards are recognized and upheld in Gia Long law. All those who commit crimes of cruelty are punished most severely. Appreciating filial piety, Volume 9, Section of Le Luat, Article 17, Stipulates: "Old people with illnesses must wait for their children to take care of them so that they can rest. If the child is with his parents, grandchildren with grandparents over 80 years of age who are seriously ill, no one in his family takes care of him, but does not return to parent,greed glory, profit... this crime ends up giving up the duty to care for parents. Or there were people who were opposite to their parents who were sick but lie that their not sick parents, don't want someone to take care of them. So one is to abandon his parents, to be inhuman, and on the other hand to be nonsense to the king, so punish 80 whips" [7]. The love of teachers and students is also appreciated, the teacher is the one who teaches morality as a person, deep gratitude, volume 15, Figure law, Article 10, Hurting teachers: "If you beat your teacher, increase by two guilty than fighting ordinary people. After beating the teacher to the disabled, handled 100 whips and exiled three thousand miles" [7].

\section{Some Comments}

From studying Confucianism imprints in law code during the Nguyen Dynasty of Vietnam, some of the following can be drawn:

Affirming the unique position of the king: Confucianism said that the king was the son of heaven, sent by heaven to rule and educate the people. Therefore, the king's power was absolute. The word of the king was the opinion of heaven (Thanh Chi). Not following the king's words, contrary to the will of the king condemned to "blasphemy", may be beheaded beheaded or may be "Chu di tam toc" (killing everyone in three generations), "Chu di cuu toc" (killing everyone in nine generations) [7]. In China, from the time of An and Zhou to Qin, that was, from the seventeenth to the third century BC, the concept of an authoritarian emperor gradually manifested in Qin Shi Huang and fully supplement under the Han Dynasty, making a model for the dynasties from Qin-Han Dynasties to Minh-Thanh Dynasties. In Vietnam was the same. The tyrannical king considers himself to be the one with the destiny of heaven, to own the whole world, to have the ownership of all resources, to consider all his subjects, to have the right and responsibility to arrange everything. The tyrannical king focused all his authority on himself.

About economy with ownership belongs to the king: all resources of land, mountains, forests, rivers and the right to use everyone's labor and control the status of everyone. The king granted land (such as dividing the land and construction), collected taxes (instead of renting land), granted fortune to the mandarins, created the "eat and wear the king's dress" gift to the mandarins and for people "inch of land, a bunch of vegetables also by the king". It was a subsidized, distributed state. There were also nobles who were granted perpetual enjoyment and the people also had their own land, but in theory it was a right to use, not ownership. The king did not divide ownership to the mandarins and the people. The king who had the right to grant land also has the right to withdraw. So apart from the king no one had the ownership of the land, the land belongs to the king.

About politic: with the notion of Heaven's destiny, the king ruled, created and abolished vassal states, appointed and removed governors at the central and local levels (stopped in the district). The king decided every political policy, organization, and control of the bureaucracy to follow. The king also mastered the "conquering, music ceremony", ie military activities, cultural, academic and artistic activities. Only the emperor has the right to "make ceremonies, compose music", that was, set forth rituals, dances, and 
music (mainly speaking dances in court and for sacrifices).

About the law: the king was the one who sets all the rules and is the one who decides the big sentences. The king's thinks is the law, the king is both a legislator, an executive and a judiciary, "Quân xử thần tử, thần bất tử bất trung" (the king who catches death must die, if not dead, he is disloyal to the king".

About military: king was the only one in power to conquer and mobilize army. The generals were assigned to hold the army but must have the king's command with the order, sword, seal and emblem of the king to command. The king did not share military power with anyone, the military general had to be under the king's control and administration. During the feudal dynasties of Vietnam established the king's standing army.

About religion: the king was the only one who was "Te" (prayed to) Heaven, Earth, and the gods of rivers and mountains, in other words the king is the lord. Moreover, the king also considered the gods as his servant so he considered himself to be able to reward and punish the gods. In the state apparatus, there is a ceremony for the administration of the gods, considering the arrangement of titles for the gods is like the order of reorganizing titles for mandarins.

\section{CONCULUSION}

Studying Hoang Viet Luat Le of Nguyen Dynasty, recognizing the imprints of Confucianism in those laws, we have the right to be proud of a legal heritage that previous generations spend a lot of effort and intellect to build and issue. Positive and good values have been and will continue to be referenced and promoted in the work of building a rule of law state, building a democratic society and developing progressively. Over the past 70 years, the Vietnamese state has continued to assert and develop the right and progressive conceptions of the monarchy states about the position and important role of law in the management and administration of the country. Regulations on the responsibilities of mandarins, on the sanctioning of negative acts are being exploited and promoted in the implementation of administrative reform and anti-corruption. Experiences and limitations in the legislative field have been consulted and applied by contemporary Vietnamese lawmakers. The profound human values of the old laws are also the basis for traditional education, building Vietnamese people who can integrate into the world, while preserving the confirmed national identity persisted throughout history. Besides, the negative factors, not suitable for today's society have also been overcome and limited.

In addition to the negative factors, it is undeniable that positive elements of Confucianism are clearly shown in the Laws, especially the 02 laws: The
Hong Duc and the Hoang Viet Luat Le. Basically and primarily, Confucianism was a political - social and ethical doctrine that has one of its main functions of educating, educating, perfecting people and stabilizing and improving feudal society. From the Han Dynasty onward, Confucianism was also an ideology and a tool of the dominance of the feudal landlords in the building, consolidation and maintenance of the central feudal state system and the feudal regime in protecting and maintaining the socio-economic base of the feudal regime and society as well as the status and interests of that class. With the above characteristics and functions, Confucianism proposed a consistent way to govern the country and the conditions and requirements to implement this line. It can be said that the idea of "administer nation" is the most important thought and content in Confucian political-social and ethical doctrine. The basic condition for Confucianism to exist, develop, have a position, role and affect Vietnamese society and people is that it must be more or less modified to suit the socio-economic basis, the literature, customs, etc. of Vietnamese society, meeting the needs of existence and development of the feudal society of Vietnam and meeting the requirements and practical tasks of Vietnamese society. Therefore, Vietnamese Confucianism cannot be "refracted", "localized", and "restructured". That is, it is filtered, developed and expanded by Vietnamese people, but as many Confucian researchers in Vietnam assert, Vietnamese Confucianism is not Chinese Confucianism, it is a product of Vietnamese people, is a core part of Vietnamese traditional culture.

\section{Declaration of ownership}

This report is my original work.

\section{Ethical clearance}

I confirm that the paper is original unpublished work, not submitted or to be submitted for consideration elsewhere. All procedures performed in studies involving human participants were in accordance with the ethical standards in academic research.

\section{REFERENCES}

1. Dai Viet Su Ky Toan Thu.(1697). "Noi cac quan ban" edition; Wood edition was carved in the 18th year of Chinh Hoa government. Volume 1. Hanoi: Social Sciences.

2. Dai Viet Su Ky Toan Thu.(1697). "Noi cac quan ban" edition; Wood edition was carved in the 18th year of Chinh Hoa government. Volume 2. Hanoi: Social Sciences.

3. Vuong, T. Q., \& Tan, H. V. (1960). History of Vietnamese feudalism, vol 1. Hanoi: Education.

4. Hiep, H. D., \& Van, V. H. (2019). The Similarities between the Political System of the Socialist Republic of Vietnam and the Laos People's Democratic Republic. Addaiyan Journal of Arts, Humanities and Social Sciences, 1(9), 56-62. 
5. Van, V. H., \& Luong, P. V. (2019). Study of the Laws under the Feudal Dynasties of Vietnam. Addaiyan Journal of Arts, Humanities and Social Sciences, 1(7).

6. Vuong, T. Q., \& Tan, H. V. (1960). History of Vietnamese feudalism, vol 2. Hanoi: Education.

7. Thuy, D. V., \& Trung, D. T. (2008). 54 Vietnamese Emperors. Hanoi: People's Army.

8. Thong, V. Q. (1973). Vietnamese legal history. Saigon: Saigon University.

9. Institute of History. (2007). Vietnamese History, vol 3. Hanoi: Social Sciences

10. Van, V. H., Phong, N. X., \& Hoang, P. D. (2019). Confucianism Perspective on the Position of Women in Society and the Impact of that
Perspective on Gender Equality in Vietnam Today. Addaiyan Journal of Arts, Humanities and Social Sciences. 1 (8).

11. Huy, N. N. (1989). Quoc Trieu Hinh Luat, book A. Hanoi: Viet Publisher.

12. Thang, N. Q. (2002). Brief survey Hoang Viet Luat Le. Hanoi: Cultural information.

13. Vinh, T. Q. (2008). Tội phạm và hình phạt trong Hoàng Việt Luật lệ.

14. The Analects.(1996). The Bible of the Chinese people (compiled by Ho Sy Diep). Vietnam: Dong Nai.

15. Waley, A., \& Wilkinson, R. (1996). Analects. Wordsworth Editions Limited. 